\title{
Pengenalan Pembicara untuk Menentukan Gender Menggunakan Metode MFCC dan VQ
}

\author{
YOULLIA INDRAWATY N, ANDRIANA, DITA PERMATASARI \\ Jurusan Teknik Informatika, Fakultas Teknologi Industri \\ Institut Teknologi Nasional Bandung \\ Email: youllia@itenas.ac.id
}

\begin{abstract}
ABSTRAK
Klasifikasi suara berdasarkan gender dibuat dengan tujuan agar komputer mampu mengenali suara laki-laki dan perempuan. Dengan kemampuan komputer yang mampu membedakan suara laki-laki dan perempuan pada pengembangan selanjutnya akan memperkuat tingkat suatu sistem keamanan yang menggunakan password dengan suara. Penelitian ini mengenai pengenalan gender dari pengucap/ pembicara dengan ucapan bergantung teks dan bergantung pembicara, dalam proses pengenalan tersebut digunakan algoritma ekstraksi yang disebut Mel Frequency Cepstral Coefficients (MFCC) digunakan untuk ekstraksi ciri dari sinyal wicara sedangkan proses pengelompokan menggunakan metode Vector Quantization (VQ). Dalam tahap pengenalan, ukuran distorsi berdasarkan minimisasi jarak Euclidean digunakan untuk mencocokkan penutur uji dengan penutur dalam database. Database wicara menggunakan 20 penutur, terdiri dari 10 penutur pria dan 10 penutur wanita dengan tingkat akurasi pria mencapai 90\% dan wanita $80 \%$.
\end{abstract}

Kata kunci : Pengenal pembicara, MFCC, VQ, Klasifikasi Gender, Bergantung Teks.

\section{ABSTRACT}

Voice classification of gender is created to recognize the voice of male or female. The ability of computer to recognize the voice of male or female in development will strengthen the level of a security system that uses a password with voice. This study is the introduction of a reciter / speaker with text dependent speech and speaker dependent speech, the recognition process is using extraction algorithm called Mel Frequency cepstral coefficient (MFCC) is used for feature extraction from speech signals and the process of grouping method is using VQ. In the introduction phase, the size of the distortion based on minimization of the Euclidean distance is used to match test speakers with database speakers. Speech database uses 20 speakers, consist of 10 male speakers and 10 female speakers with an accuracy rate of male is $90 \%$ and female is $80 \%$.

Keywords: Speaker recognition, MFCC, VQ, gender clasification, textdependent. 


\section{LATAR BELAKANG}

Klasifikasi suara berdasarkan gender dibuat dengan tujuan agar komputer mampu mengenali suara laki-laki dan perempuan. Dengan kemampuan komputer yang mampu membedakan suara laki-laki dan perempuan pada pengembangan selanjutnya akan memperkuat tingkat suatu sistem keamanan yang menggunakan password dengan suara. Pencocokan password tidak hanya berdasarkan kata saja, namun ditambah dengan pencocokan karakteristik suara sehingga akan lebih aman. Penelitian ini mengenai pengenalan gender dari pengucap/ pembicara dengan ucapan bergantung teks dan bergantung pembicara, Terdapat banyak metode yang dapat digunakan untuk pengekstraksian sinyal ucapan. Salah satu teknik pengkodean yang dapat digunakan dalam pengekstraksian sinyal ucapan adalah $\operatorname{MFCC}(\mathrm{Mel}$ Frequency Cepstral Coefficient). MFCC ini menghitung koefesien cepstral. MFCC merupakan salah satu metode yang banyak digunakan dalam bidang speech technology, baik speaker recognition maupun speech recognition.

Pada proses klasifikasi digunakan metode VQ(Vector Quantization), yang mengubah hasil ekstraksi analisis MFCC dari masing- masing pengucap menjadi sekumpulan codebook. Codebook tersebut kemudian dibandingkan dengan hasil ekstraksi koefesien MFCC dari sinyal masukan yang akan dikenali. Pengklasifikasian ditentukan dengan menghitung jarak penyimpangan . jarak penyimpangan terkecil merupakan identitas dari sinyal tersebut.

Oleh karena itu penelitian ini mengaplikasikan metode tersebut, dengan mengangkat judul, yaitu "Pengenalan Pembicara untuk Menentukan Gender menggunakan metode MFCC dan VQ". Melalui penelitian ini penulis membangun sebuah aplikasi yang berfungsi untuk mengetahui gender/jenis kelamin dari suara manusia yang sebelumnya pernah disimpan sebagai data latih.

Pada penelitian ini suara analog diubah menjadi digital dengan format * wav dengan data masukan (pada basis data) berupa sinyal suara yang diambil dari 20 orang responden (10 pria dan 10 wanita) dengan rentang usia 18- 40 tahun dalam keadaan sehat (tidak flu atau batuk). Sampling rate yang digunakan ialah $44100 \mathrm{~Hz}$, channel mono, 16 bit. Bahasa yang digunakan dalam proses latihan dan proses uji adalah Bahasa Indonesia dan diucapkan oleh orang Indonesia.

\section{METODOLOGI PENELITIAN}

\subsection{Mel Frequency Cepstral Coefficient (MFCC)}

Tahapan proses Mel Frequency Cepstral Coefficient ditunjukan pada Gambar 1

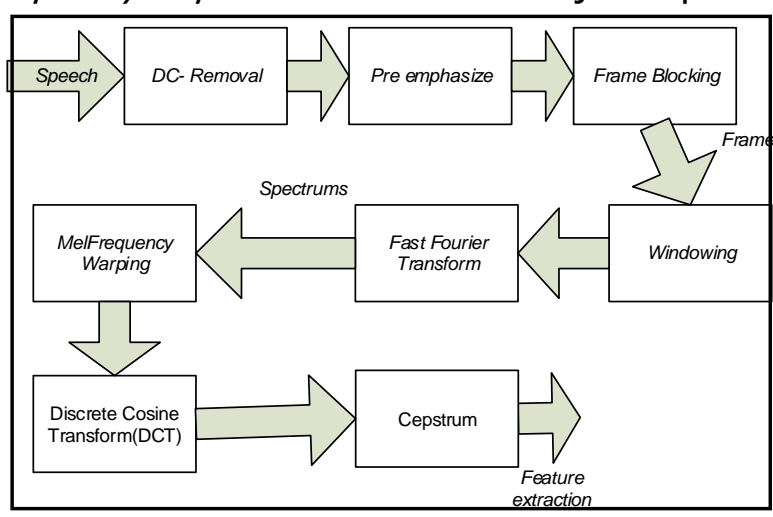

Gambar 1 Tahapan proses MFCC (Sumber: Putra, Darma dan Adi Resmawan, 2012) 
Tahapan proses Mel Frequency Cepstral Coefficient dijelaskan sebagai berikut ini:

\section{DC-Removal}

Tujuan dari DC-Removal adalah mendapat normalisasi dari data suara input.

Proses DC-Removal ini dapat dituliskan dalam persamaan (1) berikut:

Keterangan :

$$
\mathrm{y}[\mathrm{n}]=\mathrm{x}[\mathrm{n}]-\bar{x}, 0 \leq \mathrm{n} \leq \mathrm{N}-1
$$

$\mathrm{y}[\mathrm{n}]=$ Sample Signal hasil DC Removal

$x[n]=$ Sample signal asli

$\overline{\boldsymbol{x}}=$ Nilai rata-rata sample signal asli

$\mathrm{N}=$ Panajang signal

\section{Pre- emphasize Filtering}

Pre- emphasize Filtering merupakan salah satu jenis filter. Filter ini mempertahankan frekuensi- frekuensi tinggi pada sebuah spectrum, yang umumnya terliminasi pada saat proses produksi suara.

Proses Pre- emphasize ini dapat dituliskan dalam persamaan (2) berikut:

Dimana:

$$
y[n]=s[n](1-\propto), 0.9 \leq \propto \leq 1.0
$$

$\mathrm{y}[\mathrm{n}]=$ signa/hasil pre- emphasize filter

$\mathrm{s}[\mathrm{n}]=$ signal sebelum pre- emphasize filter

\section{Frame Blocking}

Pada langkah ini, sinyal ucapan yang terdiri dari S sampel $(X(S))$ dibagi menjadi beberapa frame yang berisi $\mathrm{N}$ sampel, masing-masing frame dipisahkan oleh $\mathrm{M}(\mathrm{M}<\mathrm{N})$.

\section{Windowing}

Proses windowing yang dipakai adalah proses Hamming Window, proses tersebut dapat dituliskan dalam Persamaan (3) berikut :

Dimana:

$$
w(n)=0.54-0.46 \cos =\frac{2 \pi n}{M-1}
$$

$\mathrm{N}=$ Jumlah sample pada masing- masing Frame

$\mathrm{n}=0,1,2,3, \ldots \mathrm{N}-1$

\section{FFT}

Fast Fourier Transform (FFT), yang berfungsi untuk mengubah domain waktu menjadi domain frekuensi.

Proses FFT dapat dituliskan dalam persamaan berikut:

$$
f(n)=\sum_{K=0}^{N-1}\left(Y_{k}\right) e^{-2 \pi j k n / N}, n=0,1,2,, \ldots, N-1
$$

Dengan:

$f(n)=$ frekuensi

$k=0,1,2, \ldots,(\mathrm{N}-1)$

$\mathrm{N}$ = jumlah sample pada masing-masing frame 
$j=$ bilangan imajiner $(\sqrt{ }-1)$

$\mathrm{n}=1,2,3, \ldots(\mathrm{N}-1)$

\section{Mel- frequency wrapping}

Persamaan yang digunakan untuk menghitung skala mel untuk frekuensi dalam $\mathrm{Hz}$ ditunjukan dalam Persamaan (5) berikut :

$$
\text { Mel } f=2595 * \log 10\left(1+\frac{f}{700}\right)
$$

\section{Cepstrum}

Untuk mengubah ke dalam domain waktu, maka diperlukan DCT (Discrete Cosine Transform) dengan persamaan dituliskan dalam Persamaan (6) berikut

$$
C_{n}=\sum_{k=1}^{K}\left(\log \tilde{S}_{k}\right) \cos \left[n\left(k-\frac{1}{2}\right) \frac{\pi}{k}\right], \mathrm{n}=1,2, \ldots \ldots k
$$

Dimana:

$\mathrm{Cn}=$ koefesien cepstrum mel-frequency

$\tilde{S}_{k}=$ mel frekuensi

$\mathrm{k}=$ jumlah coefficient

\subsection{VQ (Vector Quantization)}

VQ adalah proses dari pemetaan vektor dari ruang vektor yang besar menjadi sebuah wilayah yang terbatas.

\subsection{Algoritma K-Means}

Salah satu metode dasar yang digunakan untuk disain bukukode adalah algoritma iterasi yang dikenal sebagai algoritma Lloyd (K-means algorithm atau Lloyd algorithm ) [2].

Algoritma tersebut diimplementasikan dalam prosedur berulang seperti pada Gambar 2 dan langkah- langkah berikut:

1. Menentukan vektor codebook pertama, yang merupakan centroid dari keseluruhan vektor ciri.(tidak ada pengulangan pada tahap ini)

2. Gandakan ukuran codebook

3. Pencarian Nearest-Neighbour : untuk tiap vektor ciri, temukan codeword di dalam codebook tersebut (codebook saat itu) yang paling dekat(jarak penyimpangannya paling kecil), dan tempatkan vector tersebut dalam kelompok codeword tersebut.

4. Pembaharuan centroid : memperbaharui codeword pada tiap kelompok dengan menggunakan centroid dari vektor ciri terletak di sel tersebut.

5. Iterasi I : mengulang langkah 3 dan 4 sampai diperoleh jarak penyimpangan rata rata (D) yang besarnya dibawah batasan yang telah ditentukan $(\delta)$. D' merupakan nilai distorsi awal yang nilainya ditentukan pada saat inisialisasi pada awal program. 


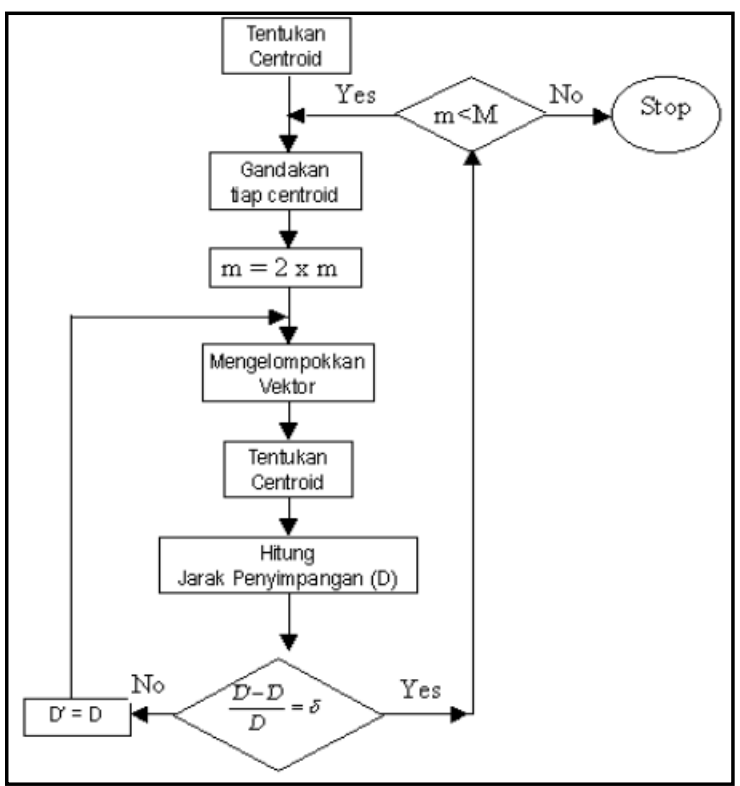

Gambar 2. Algoritma K-means

\subsection{Perhitungan Jarak Penyimpangan}

Untuk menghitung jarak penyimpangan antara dua vektor maka digunakan Euclidean distance (jarak Euclidean) [4]. Persamaan untuk menghitung jarak Eucledian Distance ditunjukan oleh Persamaan (7) berikut :

$$
d_{E}(x, c)=\sqrt{\sum_{i=1}^{d i m}\left(X_{i}-C_{i}\right)^{2}}
$$

Dimana $x$ merupakan vektor ciri dan $c$ merupakan vector dari suatu codebook. Pada pengenalan pengucap dengan menggunakan metode VQ, jarak penyimpangan Euclidean ini digunakan untuk menghitung jarak

Penyimpangan antara masing-masing vektor ciri dengan codeword pada tiap-tiap codebook, sehingga dapat diketahui codeword mana yang memiliki jarak penyimpangan terdekat dengan vektor ciri.

\subsection{Cara Kerja Sistem}

Untuk menggambarkan langkah-langkah dan urutan prosedur dari aplikasi Pengenalan pembicara untuk menentukan gender secara umum maka dibuat sebuah model kerja sistem aplikasi secara umum seperti pada Gambar 3 . 


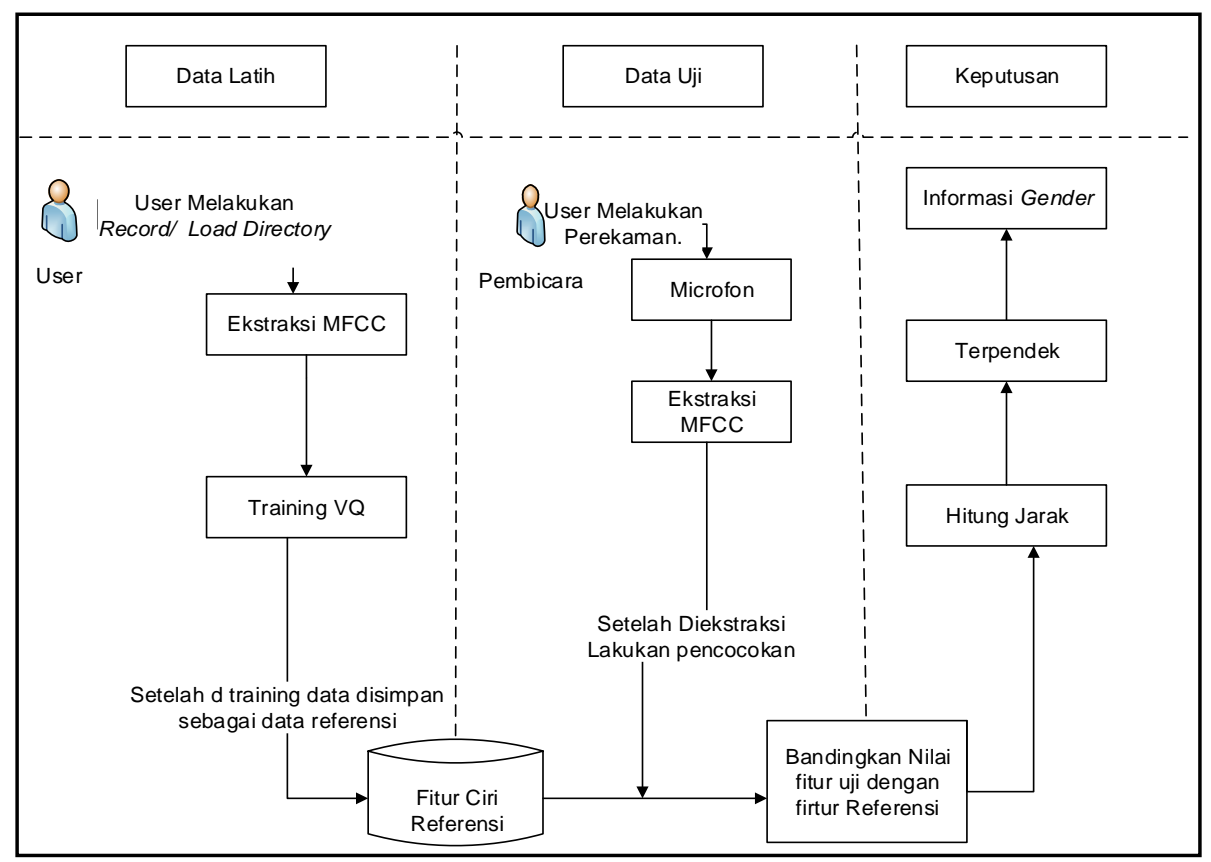

Gambar 3. Model kerja system aplikasi secara umum

Pertama user melakukan pengambilan sample suara, pengambilan tersebut dapat dilakukan dengan cara record:

recObj = audiorecorder(Fs, nbits, 1, dev_id);

atau

\section{load sound}

[nama_file nama_folder] = uigetfile $\left({ }^{1 *}\right.$.wav' $\}$, 'Ambil file suara');

$[\mathrm{y} \mathrm{Fs}]=$ wavread $([$ nama_folder nama_file $])$;

Aplikasi membaca sinyal suara yang dipilih oleh user, kemudian aplikasi memilih axes yang digunakan sebagai grafik. Sehingga terbentuk sebuah grafik sinyal suara seperti Gambar 4

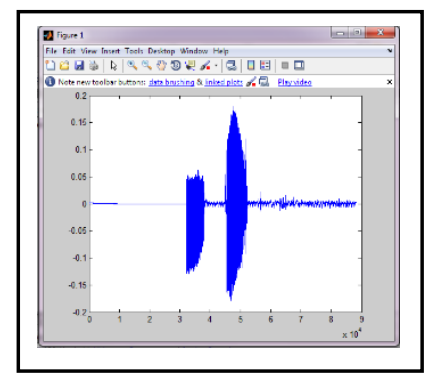

\section{Gambar 4. Grafik sinyal suara}

Kemudian suara yang masuk dilakukan proses ekstraksi ciri meggunakan metode MFCC, dengan tahapan sebagai berikut:

- DC Removal

Remove DCComponents bertujuan untuk menghitung rata-rata (nilaimean) dari data sampel suara (y_filter), dan mengurangkan setiap nilai sampel suara dengan nilai rata-rata tersebut kemudian disimpan dalam variable y_norm. 
nilaimean = mean(y_filter);

Y_norm = y_filter-nilaimean;

- Pre-emphasize

Filter ini mempertahankan frekuensi- frekuensi tinggi pada sebuah spectrum dengan cara memfilter nilai koefesien (1) dari pre-emphasize dengan nilai alpha (0.9375) kemudian disimpan kedalam variable sinyal suara $(x x)$.

$x x=$ filter $([1-0.9375], 1, x x)$;

\section{- Frame Blocking}

Frame blocking dilakukan dengan menggunakan fungsi yang telah disediakan oleh Matlab, kemudian hasilnya disimpan ke dalam variable fr.

$\mathrm{fr}=$ framing $(\mathrm{xx})$;

- Windowing

Proses ini dibutuhkan untuk meminimalisir diskontinuitas antar frame yang menyebabkan kehilangan informasi yang terdapat dalam suatu sinyal.

Windowing dilakukan dengan menggunakan fungsi yang telah disediakan oleh matlab, kemudian hasilnya disimpan kedalam variables.

$s=y . *$ hamming(256);

- FFT

Fast Fourier Transform (FFT), yang berfungsi untuk mengubah domain waktu menjadi domain frekuensi. FFT dilakukan dengan menggunakan fungsi yang telah disediakan oleh matlab, kemudian hasilnya disimpan kedalam variable $t$

$\mathrm{t}=\mathrm{abs}(\mathrm{fft}(\mathrm{s}))$;

- Mel- frequency wrapping

Mel- frequency wrapping dilakukan dengan menggunakan fungsi yang telah disediakan oleh matlab, dengan ketentuan yang digunakan pada penelitian ini yaitu jumlah mel bank=64, panjang frame= 256 dan jumlah sampling 44100 kemudian hasilnya disimpan kedalam variable bank. bank=melbankm(64,256,44100,0,0.5,'t');

- Cepstrum

Pada tahap ini, akan menghasilkan nilai MFCC yang merupakan hasil konversi log mel cepstrum ke dalam domain waktu menggunakan DCT. $\operatorname{dctcoef}\left(k_{1}:\right)=\cos \left((2 * n+1) * k^{*} \mathrm{pi} /(2 * 24)\right) ;$

aplikasi memproses suara yang telah dipilih oleh user menggunakan metode MFCC. Sehingga akan terbentuk grafik seperti Gambar 5

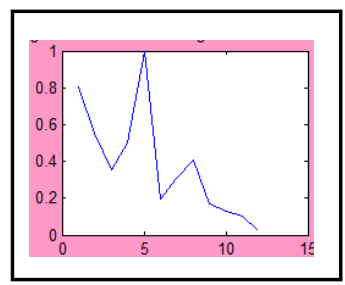

Gambar 5. Grafik proses MFCC

MIND - 40 
setelah dilakukan ekstraksi ciri, kemudian dilakukan training vector quantization dengan menggunakan algoritma k-menas untuk melakukan pengelompokan gender berdasarkan kemiripan/ kedekatan dari vektor ciri yang telah didapat dari proses ekstraksi, vektor ciri hasil training $V Q$ disimpan ke dalam database sebagai data referensi. Training VQ digunakan dengan menggunakan fungsi yang telah terdapat pada matlab dimana nilai MFCC yang dihasilkan dari ekstraksi sebelumnya yang disimpan pada variable d dan jumlah centroid yang disimpan pada variable k. Nilai hasil pengelompokan disimpan ke dalam file kmeans disimpan kedalam

kmeans.mat

$R=\operatorname{vqlbg}(d, k)$

Save kmeans. mat

Dengan menggunakan perintah tersebut maka aplikasi akan menampilkan grafik ciri yang telah ter cluster seperti pada Gambar 6

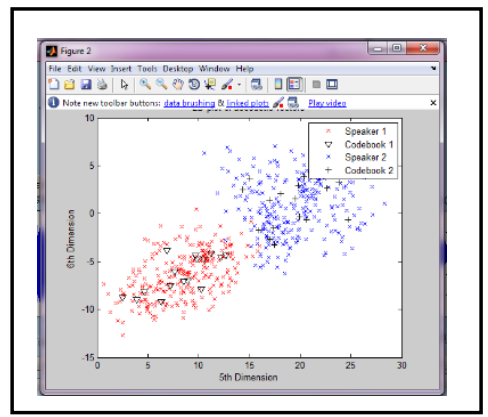

Gambar 6. Hasil Cluster ciri pembicara

Fase tersebut dinamakan dengan fase training (proses latih). Setelah dibuat data referensi pada fase latih, selanjutnya dilakukan fase testing (pengujian). Pada fase ini user kembali melakukan perekaman suara melalui microfon kemudian suara yang masuk diekstraksi ciri nya. Hasil dari ekstraksi ciri pada fase pengujian, nilai tersebut dibandingkan dengan data referensi yang terdapat pada database, proses pencocokan ini menggunakan metode VQ(vector Quantization) dengan menghitung jarak terdekat dari setiap data latih (x1) dengan data uji (x2) menggunakan perhitungan jarak Euclidean Distance. Jarak yang terpendek adalah jarak yang diidentifikasi sebagai gender tersebut. Berikut ini adalah perintah perhitungan menggunakan Euclidean Distance pada matlab:

Dist $=$ Euclidean $(x 1, x 2)$

Dist=sqrt(sum((x1(:)-x2(:)).^2));

\section{ANALISIS DAN PEMBAHASAN}

\subsection{Fungsionalitas Sistem}

Seluruh fungsionalitas yang terdapat pada aplikasi akan dinyatakan pada use case diagram. Use case diagram dapat dilihat pada Gambar 7. 


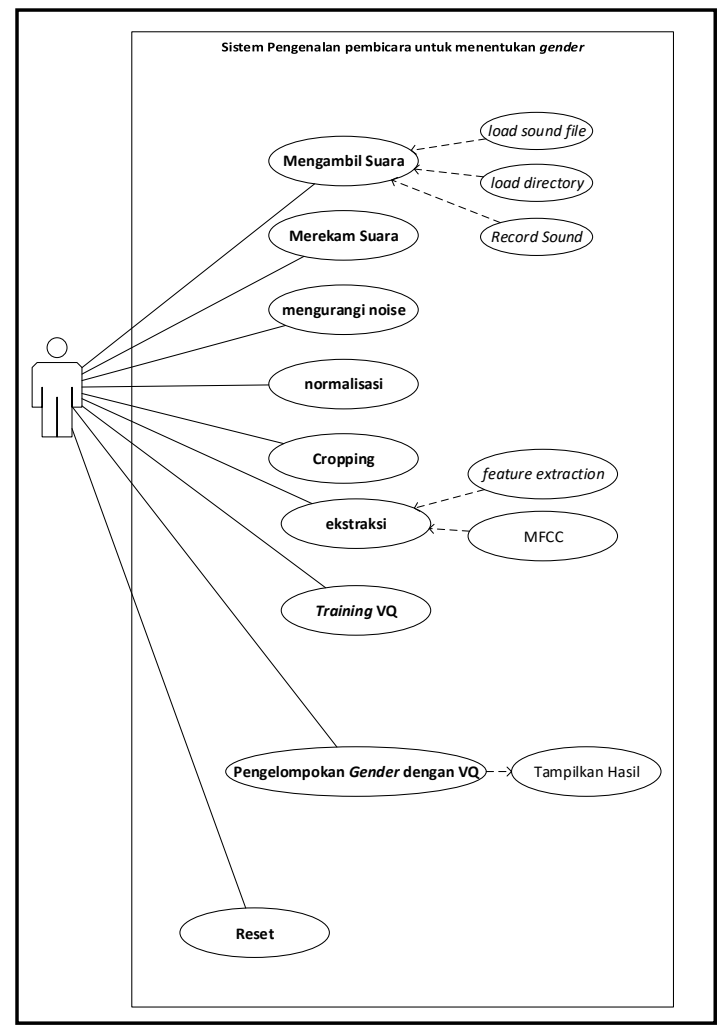

Gambar 7. Usecase fungsionalitas sistem

\section{Tampilan Halaman Menu Utama}

Form utama merupakan antarmuka yang ditampilkan pada awal dari aplikasi pengenalan Gender melalui suara. Form ini berisi 3 button untuk mengakses form Latih, form uji, form real time ditampilkan pada Gambar 8

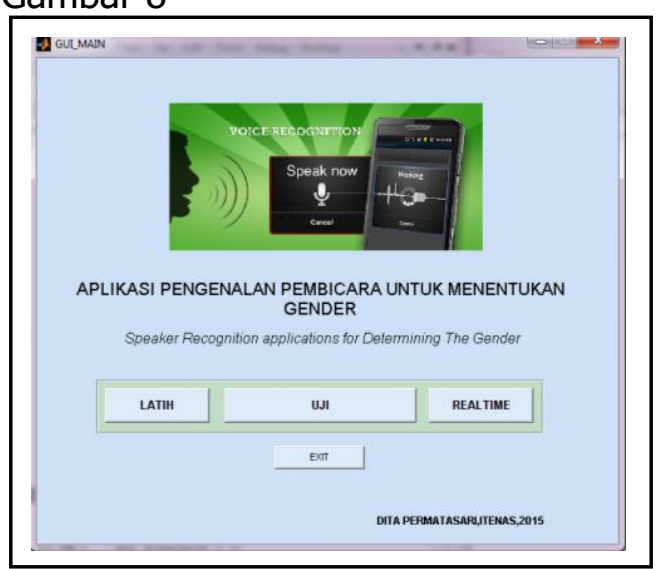

\section{Gambar 8. Halaman Menu}

\section{Tampilan Halaman Latih Suara}

Form Latih suara seperti pada Gambar 9 merupakan antarmuka dari program pengenalan pembicara untuk menentukan Gender. Dalam implementasinya antar muka ini pengguna melakukan proses ekstraksi dan training VQ. Suara yg digunakan untuk melakukan poses 
pelatihan ini dalam format .wav. proses pengambilan sample suara ini dapat dilakukan dengan melakukan load file dan untuk mendengarkan file suara yang sudah di load maka dibuat tombol play. Kemudian untuk melakukan proses ekstraksi dilakukan dengan menekan button MFCC yang sebelumnya telah dilakukan proses normalisasi, denoising dan cropping. Atau dapat dilakukan dengan menekan tombol button load sound directory untuk melakukan ekstraksi satu folder sekaligus dengan menekan tombol feature extraction. Dan untuk melakukan pengelompokan sinyal suara yang telah dilakukan ekstraksi dilakukan proses training VQ dengan menekan button training VQ. Sinyal- sinyal suara dari proses- proses tersebut juga ditampilkan pada form ini. Untuk menghilangkan sinyal- sinyal suara yang telah diproses disediakan button reset.

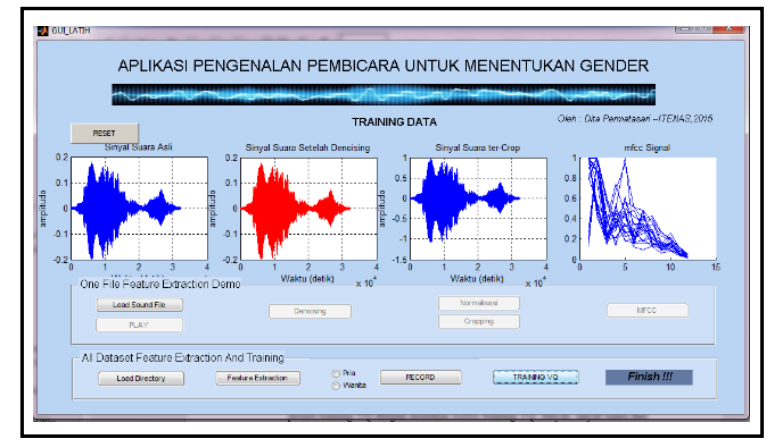

Gambar 9. Halaman Training Suara

\section{Tampilan Halaman Uji Suara}

Form pengujian ucapan suara seperti pada Gambar 10 diperuntukan untuk melakukan pengujian pembicara yang sebelumnya pernah terdaftar di dalam database. Form pengujian ini di tampilkan pada Gambar. Dalam implementasinya pengguna melakukan load file untuk menentukan suara mana yang akan diujikan sebagai pengenalan gender. Kemudian pengguna melakukan proses denoising dengan menekan button denoising dan melakukan proses normalisasi \& cropping dengan menekan tombol normalisasi \& cropping. Suara yang telah di load dan melewati proses tersebut kemudian diekstraksi menggunakan MFCC, untuk melakukan ekstraksi tersebut dapat dilakukan dengan menekan button MFCC. Pengguna yang telah melakukan tahapan tersebut kemudian dilakukan perbandingan dengan suara yang ada di referensi.

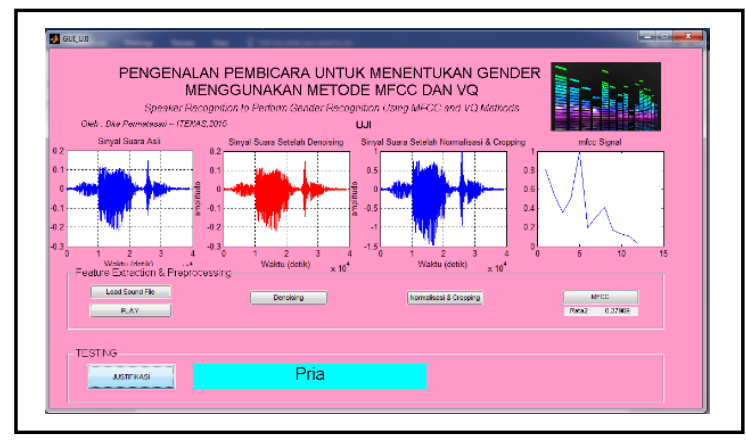

Gambar 10. Halaman Uji Suara

\section{Tampilan Halaman Real Time}

Form real time seperti pada Gambar 11 ini sama dengan form pengujian ucapan yang fungsinya juga sama diperuntukan untuk melakukan pengujian pembicara yang sebelumnya pernah terdaftar di dalam database. Dalam implementasinya pengguna melakukan recod sound file untuk dijadikan suara yang akan diujikan untuk pengenalan gender. Kemudian pengguna melakukan proses denoising dengan menekan button denoising dan melakukan proses normalisasi \& cropping dengan menekan tombol normalisasi \& cropping. Suara yang 
telah di load dan melewati proses tersebut kemudian diekstraksi menggunakan MFCC, untuk melakukan ekstraksi tersebut dapat dilakukan dengan menekan button MFCC. Pengguna yang telah melakukan tahapan tersebut kemudian dilakukan perbandingan dengan suara yang ada di referensi.

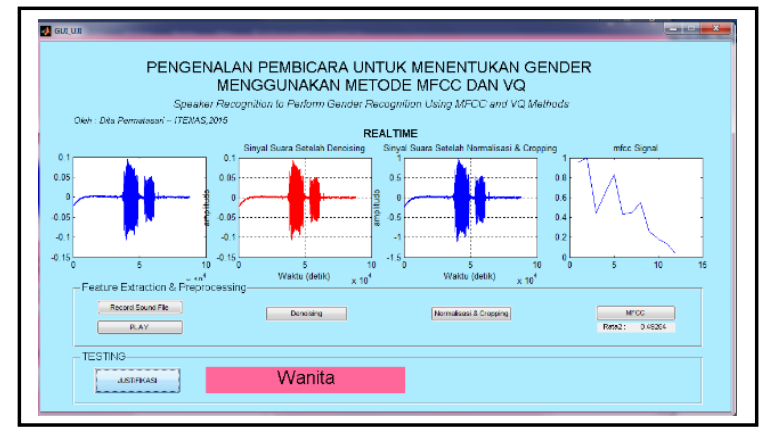

Gambar 11. Halaman Real Time

\subsection{Pengujian Offline}

Pengujian dilakukan oleh 20 orang yang terdiri dari 10 pria dan 10 wanita dengan melakukan load data. Masing- masing orang diambil sample suaranya dengan mengucapkan kata yang sama yaitu kata "baju".

Hasil pengujian suara pria ditunjukan oleh Tabel 1.

Table 1. hasil uji pria mengucapkan kata sama dengan data latih

Keterangan Tabel 1.

\begin{tabular}{|c|c|c|c|c|}
\hline No & Nama & Usia & pekerjaan & Genderyang terdeteksi \\
\hline 1 & Adhe & 22th & Mahasiswa & $\mathrm{P}$ \\
\hline No & Nama & Usia & pekerjaan & Genderyang terdeteksi \\
\hline 2 & Andri & 22th & Mahasiswa & $\mathrm{P}$ \\
\hline 3 & Asep & 20th & Mahasiswa & $\mathrm{P}$ \\
\hline 4 & Eka & 24th & Mahasiswa & $\mathrm{W}$ \\
\hline 5 & Fahmi & 20th & Mahasiswa & $\mathrm{P}$ \\
\hline 6 & Hafiz & 20th & Mahasiswa & $\mathrm{P}$ \\
\hline 7 & Rifky & 22th & Mahasiswa & $\mathrm{P}$ \\
\hline 8 & Toni & 23th & Mahasiswa & $\mathrm{P}$ \\
\hline 9 & Yoga & 20th & Mahasiswa & $\mathrm{P}$ \\
\hline 10 & M.eka & 22th & Mahasiswa & $\mathrm{P}$ \\
\hline
\end{tabular}

P : Pria W : Wanita

Hasil pengujian suara wanita ditunjukan oleh Tabel 2. 
Table 2. hasil uji wanita mengucapkan kata sama dengan data latih

\begin{tabular}{|c|c|c|c|c|}
\hline No & Nama & Usia & pekerjaan & Genderyang terdeteksi \\
\hline 1 & Dinda & 18th & Mahasiswa & W \\
\hline 2 & Dita & 22th & Mahasiswa & W \\
\hline 3 & Fuzna & 23th & Pegawai & P \\
\hline 4 & Intan & 18th & Mahasiswa & W \\
\hline 5 & Isty & 23th & Megawai & W \\
\hline 6 & Nadia & 18th & Mahasiswa & W \\
\hline 7 & Novi & 23th & Pegawai & W \\
\hline 8 & Nur & 22th & Pegawai & W \\
\hline 9 & Dinda2 & 25th & Mahasiswa & W \\
\hline 10 & Eva & 22th & Pegawai & \multicolumn{2}{c|}{} \\
\hline
\end{tabular}

Keterangan Tabel 2.

P : Pria W : Wanita

\section{Total Hasil Pengujian}

Tabel 1 dan tabel 2 menunjukan hasil pengujian dari sample suara. Tingkat kesuksesan dalam persen(\%) dapat dihitung dengan cara :

\section{Presentase matching $=$}

$$
\frac{\text { Hasil Yang Sesuai/Benar }}{\text { Total Seluruh Uji Coba }} \times 100 \%
$$

Tingkat kesuksesan dalam persen(\%) untuk pengujian yang terdiri dari 10 orang wanita yang pembicara dan kata nya sama dengan data latih adalah sebagai berikut:

$$
\frac{8}{10} \times 100=80 \%
$$

Sedangkan pada 10 orang pria adalah sebagai berikut:

$$
\frac{9}{10} \times 100=90 \%
$$

\section{Pengujian Online}

Pengujian dilakukan oleh 20 orang yang terdiri dari 10 pria dan 10 wanita dengan melakukan record secara real time. Masing- masing orang diambil sample suaranya sebanyak 10 kali dengan mengucapkan kata yang sama yaitu kata "baju" .

\begin{tabular}{|c|c|c|c|c|c|c|c|c|c|c|c|c|c|c|}
\hline \multirow{2}{*}{ No } & \multirow{2}{*}{ Nama } & \multirow{2}{*}{ Usia } & \multirow{2}{*}{ pekerjaan } & \multicolumn{10}{|c|}{ Gender yang terdeteksi } & \multirow{2}{*}{$\begin{array}{l}\text { Jumlah } \\
\text { Benar }\end{array}$} \\
\hline & & & & 1 & 2 & 3 & 4 & 5 & 6 & 7 & 8 & 9 & 10 & \\
\hline 1 & Adhe & 22th & Mahasiswa & $\mathrm{P}$ & $\mathrm{P}$ & $\mathrm{P}$ & $\mathrm{P}$ & $r$ & $P$ & $P$ & $P$ & $\mathrm{P}$ & $\mathrm{P}$ & 10 \\
\hline 2 & Andri & 22th & Mahasiswa & w & w & $\mathrm{P}$ & W & $\mathrm{P}$ & w & w & $\mathrm{P}$ & $\mathrm{P}$ & $\mathrm{P}$ & 5 \\
\hline 3 & Asep & 20th & Mahasiswa & $P$ & $\mathrm{P}$ & w & $\mathrm{P}$ & $\mathrm{P}$ & $\mathrm{P}$ & $P$ & w & w & $\mathrm{P}$ & 7 \\
\hline 4 & Eka & 24th & Mahasiswa & w & $\mathrm{P}$ & w & $\mathrm{P}$ & $\mathrm{P}$ & w & $\mathrm{P}$ & $\mathrm{P}$ & $\mathrm{P}$ & $\mathrm{P}$ & 7 \\
\hline 5 & Fahmi & 20th & Mahasiswa & $\mathrm{P}$ & w & $\mathrm{P}$ & $\mathrm{P}$ & w & $\mathrm{P}$ & w & w & w & w & 4 \\
\hline 6 & Hafiz & 20th & Mahasiswa & $\mathrm{P}$ & W & $\mathrm{P}$ & $\mathrm{P}$ & $\mathrm{P}$ & $\mathrm{P}$ & $P$ & $\mathrm{P}$ & $\mathrm{P}$ & $\mathrm{P}$ & 9 \\
\hline 7 & Rifky & 22th & Mahasiswa & $\mathrm{P}$ & $\mathrm{P}$ & $\mathrm{P}$ & $\mathrm{P}$ & $P$ & w & $\mathrm{P}$ & $\mathrm{P}$ & $\mathrm{P}$ & $\mathrm{P}$ & 9 \\
\hline 8 & Toni & 23th & Mahasiswa & $\mathrm{P}$ & $\mathrm{P}$ & $\mathrm{P}$ & $\mathrm{P}$ & $\mathrm{P}$ & $\mathrm{P}$ & w & $\mathrm{P}$ & $\mathrm{P}$ & $\mathrm{P}$ & 8 \\
\hline 9 & Yoga & 20th & Mahasiswa & $\mathrm{P}$ & w & $p$ & $\mathrm{P}$ & w & w & $P$ & w & w & w & 4 \\
\hline 10 & M.eka & 22th & Mahasiswa & $\mathrm{P}$ & $\mathrm{P}$ & $\mathrm{P}$ & W & $\mathrm{P}$ & $\mathrm{P}$ & w & W & w & W & 4 \\
\hline
\end{tabular}

Hasil pengujian suara pria ditunjukan oleh Tabel 7.

Table 3. hasil uji online pria yang mengucapkan kata yang sama dengan data latih 
Hasil pengujian suara wanita ditunjukan oleh Tabel 8.

Table 4. hasil uji online wanita yang mengucapkan kata yang sama dengan data latih

\begin{tabular}{|c|c|c|c|c|c|c|c|c|c|c|c|c|c|}
\hline \multirow{2}{*}{ No } & \multirow{2}{*}{ Nama } & \multirow{2}{*}{ Usia } & \multirow{2}{*}{ pekerjaan } & \multicolumn{9}{|c|}{ Gender yang terdeteksi } & \multirow{2}{*}{\begin{tabular}{|l} 
Jumlah \\
Benar
\end{tabular}} \\
\hline & & & & 1 & 2 & 3 & 4 & 5 & 6 & 7 & \begin{tabular}{l|l}
8 & 5
\end{tabular} & 10 & \\
\hline 1 & Dinda & 18th & Mahasiswa & $\mathrm{W}$ & $\mathrm{W}$ & W & $P$ & W & $\mathrm{P}$ & $\mathrm{w}$ & $\mathrm{W} / \mathrm{H}$ & W & 7 \\
\hline 2 & Dita & 22 th & Mahasiswa & $\mathrm{w}$ & $\mathrm{W}$ & $P$ & $P$ & $\mathrm{~W}$ & $\mathrm{w}$ & $P$ & $\mathrm{~W}$ & $\begin{array}{ll}\mathrm{P} \\
\mathrm{V}\end{array}$ & 6 \\
\hline 3 & Fuzna & 23th & Pegawai & W & $P$ & $\mathrm{~W}$ & W & $\mathrm{P}$ & $\mathrm{P}$ & $\mathrm{w}$ & $\mathrm{w}$ & P & 6 \\
\hline 4 & Intan & 18th & Mahasiswa & $\mathrm{W}$ & $\mathrm{W}$ & $P$ & $P$ & $\mathrm{~W}$ & $P$ & $\mathrm{P}$ & $\mathrm{W} / \mathrm{H}$ & 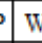 & 5 \\
\hline 5 & Isty & 23th & Megawai & W & $\mathrm{W}$ & W & W & W & $P$ & $\mathrm{w}$ & $\mathrm{W} / \mathrm{F}$ & $\mathrm{W}$ & 8 \\
\hline 6 & Nadia & 18 th & Mahasiswa & $\mathrm{W}$ & $P$ & $\mathrm{~W}$ & $\mathrm{w}$ & $\mathrm{P}$ & $\mathrm{W}$ & $\mathrm{w}$ & $\mathrm{W}$ & W & 7 \\
\hline 7 & Novi & 23th & Pegawai & $P$ & $\mathrm{~W}$ & $P$ & $\mathrm{~W}$ & $P$ & $\mathrm{~W}$ & $\mathrm{~W}$ & $P \mathrm{P}$ & $\mathrm{W}$ & 6 \\
\hline 8 & Nur & 22 th & Pegawai & $\mathrm{P}$ & $\mathrm{W}$ & W & $w$ & W & $\mathrm{W}$ & $\mathrm{w}$ & $\mathrm{WV}$ & $\mathrm{W}$ & 9 \\
\hline 9 & Dinda2 & 25 th & Mahasiswa & $\mathrm{W}$ & $P$ & $P$ & $\mathrm{~W}$ & W & $P$ & $P$ & $\mathrm{P}$ & P & 4 \\
\hline 10 & Eva & 22 th & Pegawai & $P$ & $\mathrm{~W}$ & $\mathrm{P}$ & $P$ & $P$ & $\mathrm{w}$ & $\mathrm{P}$ & \begin{tabular}{l|l}
$\mathrm{P}$ & $\mathrm{V}$ \\
\end{tabular} & V $P$ & 3 \\
\hline
\end{tabular}

Tingkat kesuksesan dalam persen(\%) untuk pengujian yang terdiri dari 10 orang wanita yang pembicara dan kata nya sama dengan data latih adalah sebagai berikut:

$$
\frac{50}{100} \times 100=61 \%
$$

Sedangkan pada 10 orang pria adalah sebagai berikut:

$$
\frac{48}{100} \times 100=67 \%
$$

\section{KESIMPULAN}

Berdasarkan hasil penelitian serta pengujian sistem yang telah dilakukan kepada 10 orang pria dan 10 orang wanita, maka dapat disimpulkan bahwa tingkat kesuksesan pengenalan pembicara yang dapat dikenali pada pengujian offline pria mencapai $90 \%$ dan wanita mencapai $80 \%$. Sedangkan pada pengujian online pria mencapai $67 \%$ dan wanita mencapai $61 \%$. Data yang sebelumnya tidak pernah dijadikan data latih akurasinya tidak lebih baik dari akurasi data yang sebelumnya pernah dijadikan data latih. Sehingga metode MFCC dan VQ terbukti cukup baik untuk memperkuat tingkat suatu sistem keamanan dengan suara. Kegagalan penelitian dapat diakibatkan oleh keadaan lingkungan atau keadaan dari pembicara.

\section{DAFTAR PUSTAKA}

[1] Agustini, Ketut, 'Biometrik Suara Dengan Transformasi Wavelet'. Di unduh 18 Maret 2015.

[2] Elfitri, Ikhwana, 'Kuantisasi Vektor : Definisi, Design dan Kerja'. No.29, Volume 1, Tahun XV, April 2008, Di unduh 18 April 2015.

[3] Lawrence Rabiner, dkk. 1993. 'Fundamental of Speech Recognition'. Prentice Hall PTR

[4] Mustofa, Ali, 'Sistem Pengenalan Penutur dengan metode Mel-Frequency Wrapping'. Jurnal Teknik Elektro vol.7, No.2, September 2007:88-96.

[5] Putra, Darma dan Adi Resmawan, Juni 2011 , 'Verifikasi Biometrika Suara Menggunakan Metode MFCC dan DTW'.

[6] "___, 'Pengenalan Pola'. https://id.wikipedia.org/wiki/Pengenalan_pola. Diunduh pada tanggal 09 Agustus 2015. 
[7] Setiawan, Arif, 'Analisis Klasifikasi Suara Berdasarkan Gender Dengan Format Wav Menggunakan Algoritma K-Means'. http://eprints.umk.ac.id/79/1/ANALISIS_KLASIFIKASI_SUARA_BERDASARKAN_GENDER. pdf. Diunduh pada tanggal 20 Agustus 2015.

[8] Aditya, Eko, dkk. 'Klastering Suara Laki-Laki dan Perempuan Menggunakan Algoritma KMeans Berdasarkan Hasil Ekstraksi FFT (Fast Fourier Transform)'. http://yudistira.lecture.ub.ac.id/files/2014/04/Klastering-Suara-Laki-Laki-dan-PerempuanMenggunakan-Algoritma-K-Means-Berdasarkan-Hasil-Ekstraksi-FFT.pdf. Diunduh pada tanggal 25 November 2015

[9] Bagas, Susetyo dan Altedzar Riedho W. Seminar Nasional Aplikasi Teknologi Informasi 2012 (SNATI 2012). Yogyakarta, 15-16 Juni 2012. 'Aplikasi Pengenalan Gender Menggunakan Suara '. Diunduh pada tanggal 10 November 2015 